\title{
Economic Impact Assessment of Climatic Change Sensitivity in Rice-Wheat Cropping System of Pakistan
}

\author{
Tayyaba Hina ${ }^{1}$, Sultan Ali Adil', Muhammad Ashfaq'and Ashfaq Ahmad ${ }^{2}$ \\ 'Institute of Agricultural and Resource Economics, University of Agriculture Faisalabad, Faisalabad-38000, Punjab, \\ Pakistan; tayyaba_hina@outlook.com,sultan.adil@uaf.edu.pk, ashfaq9@hotmail.com \\ 2Department of Agronomy, University of Agriculture Faisalabad, Faisalabad-38000, Punjab, Pakistan; \\ ashfaqchattha@uaf.edu.pk
}

\begin{abstract}
Objectives: To measure the impacts of climate change sensitivity and how it is affecting economic conditions of farmers in current rice wheat cropping system. Methods/Statistical analysis: Cross-sectional data of 210 farmers from the seven different strata were collected from Punjab, Pakistan. Climate data of baseline (1980-2010) and future (2039-2040) under representative concentration pathways 4.5 and 8.5 for five global circulation models were collected from secondary sources. The climate scenarios were used in two crop simulation models, i.e., DSSAT and APSIM. Tradeoff Analysis Model for Multidimensional Impact Assessment (TOA-MD) was used for the economic analysis. Findings: The crop modeling results of the study using different GCMs and RCPs show that there was negative impact of climate change on the yields of both major crops i.e., rice and wheat. The comparison of both CSMs given the insight that the percent losses were higher in APSIM as compared to DSSAT. The economic analysis endorsed the negative impacts of climate change on farming community. The major economic indicators (net returns, per capita income and poverty) of the study area expressed the declining trend in both RCPs (4.5 and 8.5) and all five GSMs. The observed household vulnerability to climate change percentage was more intense in RCP 8.5 as compared to RCP 4.5, however, among GCMs the figures shown higher vulnerability in hot dry climate conditions and lower in cool wet. The poverty of the study area increased with climate change and it was more prominent while using RCP 8.5 as compared with RCP 4.5.The highest increase in poverty was observed using APSIM crop model for hot-dry conditions. Application/Improvements: The study concluded that to ensure food security, poverty alleviation and to minimize climatic risks there is the need to update agronomic practices and develop adaptation strategies.
\end{abstract}

Keywords: Climatic Change Sensitivity, Economic Assessment of Climate Change, Pakistan, TOA-MD, Rice Wheat Cropping System

\section{Introduction}

The most threatening concern of this century for the coming generations is climate change (CC), and the expected consequences of it would be considerable ${ }^{\frac{1-3}{3}}$.The climate variability and change have substantial impacts on all biological and human systems $s^{4}$. The problem of climate change gets worse because its impacts could be felt at the places far beyond its origin ${ }^{5}$. Climate change intensity and effects vary in different regions, countries, sectors and communities according to the prevailing environmental conditions ${ }^{7}$. Cool temperate regions will observe the positive impacts on climatic factors such as temperature and precipitation while the tropical regions with already hot climatic conditions will face further rise in average temperature due to $\mathrm{CC}$ over the period of time $e^{5,6,7}$. The potential climate change risks disturb the whole economic system. Among all major sectors of an economy agriculture is more prone and susceptible to climatic changes. As a result, the developing countries get worse off due to

${ }^{*}$ Author for correspondence 
climate change because of the high dependence of their economies on agriculture sector $\frac{89}{9}$.

Agricultural farming systems are diverse because of their inherent link to climate and natural resources (water and soil), which make it most susceptible to the changes in climate $\frac{10-12}{2}$. The global food system is at risk due to one of the most concerning issues of agricultural vulnerability to climate change ${ }^{13,14}$. Worldwide, millions of households depending upon agriculture for the livelihood are fluctuating above and below poverty line because of climate variability. These climatic variabilities and changes are a constant threat to the food security and stable food supply by impacting availability, accessibility and utilization of food $15-17$.

Climate change excessively affects farmers with small landholding and limited financial stability by further worsening the risks that they face $\frac{18}{}$. Adverse impacts of CC on agricultural production and the linked livelihoods have been observed especially in recent two-three decades $\underline{\underline{19}-\underline{23}}$. The identified impacts as stunted crop growth and increase in pest attacks lower the crop yields, hence, reducing the crop revenue worsening the situation of food insecurity ${ }^{24-27}$.

In South Asia, the rise in temperature more than the global average is a major concern for the existing ecological, economic systems and especially for the sensitive sectors; water, biodiversity and agriculture ${ }^{8,28}$. The increasing climatic concern for the region is due to less adaptive behavior of the countries. Therefore, the food security situation is also very poor in this region. South Asia will be home to highest figure of food insecure masses in the coming years ${ }^{29,30}$. Pakistan is one of the most affected countries in South Asia to climate change ${ }^{31,32}$. Global Climate Risk Index and the World Bank report have placed Pakistan at $7^{\text {th }}$ position in the index of the countries facing climatic extremes in the time period 1998-2012 $2^{33}$.

By the year 2100, the increase in temperature will decline the yields of cereal crops 25 to 30 percent and the water availability will decline to 37 percent in South Asian region 34,35 . The other threat to the agricultural production systems of the region is uneven rainfall patterns, risks of floods and droughts which will lower the crop production. Different studies in Pakistan have revealed that cereals and other crop productions are expected to decline due to rise in temperature ${ }^{36,37}$. Wheat production in arid, semiarid and sub-humid regions of Pakistan would decline by 6 to 9 percent while it is expected to increase in the humid areas ${ }^{38}$. In the northern areas of Pakistan, for swat district, the increase in temperature by 1.5 to $3^{\circ} \mathrm{C}$ would decrease the wheat production by 7 to 21 percent, and for district Chitral, the decrease would be 14 to 23 percent 39,40 . The declining effect of the rise in temperature on rice yield for semi-arid regions of Pakistan could decline by 15 percent for early midcentury 2012 to 2039 and 36 percent for late century 2070-20994142. Decreasing rainfall effects on crop production are also negative. The net irrigation water requirements in Pakistan will increase by 30 percent by 6 percent decrease in rainfall. The negative effects of decreasing rainfall would affect 1.3 million rural farm households in Pakistan for cereal crops, fruits, and vegetables ${ }^{\frac{43}{}}$.

Climate models suggest that temperature will increase up to $0.5-2^{\circ} \mathrm{C}$ by 2030 and between $1-7^{\circ} \mathrm{C}$ by 2070 in the Asian Pacific region ${ }^{44}$. Wheat crop is sensitive to rise in temperature at the early stages of crop growth. The higher temperature than $30^{\circ} \mathrm{C}$ can accelerate senescence by damaging leaf photosynthetic system which results in a reduction of grain filling ${ }^{45}-\underline{47}$. Rice crop is little less sensitive to a high temperature before microsporogenesis, and at tilling stage of crop growth, the temperature range between $27-32^{\circ} \mathrm{C}$ is optimal ${ }^{48}$. Temperature above this may lead to pollen unavailability, reduced pollen disposition, embryo abortion, and spikelet sterility ultimately lowering grain yield $\underline{48}-\underline{50}$. High night time temperature is also a concern for Rice. However, challenges other than rise in temperature for both rice and wheat due to climate are increase in floods, soil salinity, pest attack, weed competition, though these issues vary with geographical location and crop management practices $\underline{51-53}$.

Indo-Gangetic Plains are the hub of rice-wheat cropping system (RWCS) and almost cover about 13 million hectares from Pakistan to Bangladesh. Rice and wheat are the key global food crops which are vital to ensure food security. Rice and wheat are the two main staple cereal crops of Pakistan and are grown almost in all agroecological zones of the country in different climatic and hydrological conditions ${ }^{54}$. The concern about the productivity of Rice and Wheat crops is very crucial because these two crops contribute about 20 and 75 percent in average daily calorie intake of Pakistanis ${ }^{55}$. The study area was chosen for the significance of both major crops of agriculture sector wheat and rice in the food security situation of the country.

There is a plethora of research on climate change and its impacts on agriculture. And recent literature in last two decades has evolved from research on mitigation 
strategies $\underline{\underline{56}-\underline{59}}$ to climate change impact assessment $\underline{\underline{60}-\underline{64}}$. The studies on climatic change sensitivity on the integrated agricultural production system for Pakistan are rare and few ${ }^{3,63,65-67}$. The focus of the previous studies was either on crop modelling or econometric modeling. This study is unique and innovative in the sense that it uses an integrated approach using climate, crop, and economic modeling.

The study also included representative agricultural pathways (RAPs) for the non-modelled activities (minor crops and livestock) as RAPs are the climate, economic and social environment, or socio-economic settings in which production systems operate. These are basically qualitative storylines, which are developed with the help of a team of a transdisciplinary scientist by following the nested approach as was used by IPCC for $\mathrm{SSP}^{6}{ }^{68}$. The impact of climate change in this study is calculated on current integrated rice-wheat cropping system (including major, minor crops and livestock) for both mild and harsh RCPs (4.5 and 8.5), using APSIM and DSSAT crop simulation models. Undertaking the integrated climatecrop-economic modelling assessment is important to enable a wide-ranging investigation of climate change impacts on agriculture sector, to characterize the actual situation of food security and poverty of the study region and also to highlight how the climatic changes affect the future agricultural productions ${ }^{69,70}$.

Specifically, the basic objectives of the study are; what is the impact of climatic change sensitivity on the integrated RWCS across different RCPs and GCMs? And what is the impact of climatic changes on the socioeconomic conditions (Net Returns (NR), Per Capita Income (PCI), and poverty) of the farmers? The remainder of the paper is followed by the materials and methods in section 1. Results of the analysis are provided in section 2. Section 3 provides the discussions of the results and conclusions are provided in section 4 .

\section{Materials and Methods}

\subsection{Description of the Study Area}

In Pakistan, Punjab is the most populated province and contributes the largest share in national agriculture production sector. There are five major agro-ecological zones of Punjab province namely, Cotton-Wheat zone, RiceWheat zone, Mixed-Cropping zone, Low-Intensity zone,
Rain-Fed zone. Rice-Wheat zone is specifically chosen for the study because of its importance in ensuring food security of the country and the importance of export revenue earned through both crops. The rice-wheat cropping system is the major one which account for total $2.2 \mathrm{mha}$ of area, supporting the livelihood of 1.1 million farm families ${ }^{71}$. In Pakistan, the rice-wheat cropping areas are mainly located in central Punjab (main districts include Sheikhupura, Nankana Sahib, Hafizabad, Gujranwala, Sialkot, Gujrat and Mandi Bahauddin) followed by Sindh. The study covers RWCS of Punjab province comprising on the seven famous strata mentioned earlier, forming a heterogeneous sample size.

\subsection{Collection of Farm Surveyed Data}

Both primary and secondary data were collected and used in this study. Primary data were collected from farmers after taking their consent to provide information using a well-structured questionnaire. For secondary data, different government sources and surveys, i.e., Soil Surveys, Economic Surveys, Pakistan Meteorological Department and Pakistan Bureau of Statistics were used.

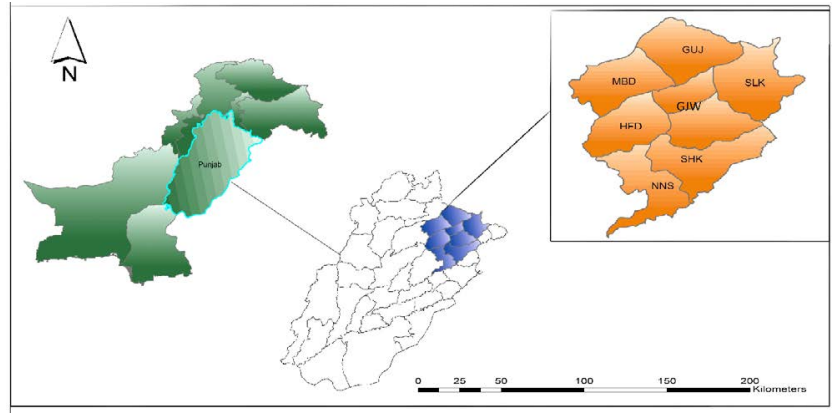

Figure 1.Map of the study area.

The farming population is heterogeneous, so, multistage stratified random sampling technique was employed to collect the primary data following Naseer, Ashfaq ${ }^{72}$. In the first stage, the RWCS was chosen for this study due to its importance of both major crops rice and wheat, used as staple food. In the second stage, seven rice-producing districts were chosen from the RWCS, i.e., Sheikhupura, Nankana Sahib, Hafizabad, Gujranwala, Sialkot, Gujrat and Mandi-Bahauddin which form the seven strata of the study (Figure 1). In the third stage, three villages from each stratum were chosen randomly. In the last stage, ten respondents from each village were chosen randomly which makes the total sample size of 210 respondents. 


\subsection{Climate Change Projections}

A baseline daily weather dataset (1980-2009) was collected from Pakistan Metrological Department (PMD) and calibrated for future scenarios by using a well-developed climatic methodology following Coupled Model Intercomparison Project (CMIP5) ${ }^{73}$. Statistical downscaling and climate change scenarios were produced by Pakistan Metrological Department (PMD), a method described by Ruane, Goldberg ${ }^{74}$. Future climatic projections of the midcentury 2040-2069 were made for both RCP 4.5 (mild climatic conditions) and RCP 8.5 (harsh climatic conditions). The carbon dioxide concentration of 499ppm were used for RCP 4.5 and $571 \mathrm{ppm}$ for RCP $8.5^{\frac{75}{5}}$.

Future climate scenarios were developed by using GCMs, representing physical processes in the atmosphere, ocean, cryosphere and land surface. GCMs are the most advanced tools currently available for simulating the response of the global climate system to increasing greenhouse gas concentrations. For this study five best GCMs were used. These models were same for both RCPs (4.5 and 8.5) and are namely; BCC-CSM (cool wet), CCSM4 (cool dry), BNU-ESM (middle), CMCC-CM (hot dry) and MIROC-ESM (hot wet).

\subsection{Crop Modeling}

In this study, two famous Crop Simulation Models (CSMs); the Agricultural Production Systems Simulator (APSIM) $\frac{76}{}$ version 7.5 and the Decision Support System for Agrotechnology Transfer (DSSAT) ${ }^{77,78}$ version 4.6 were used and economic results were evaluated using the simulated yields of both CSMs (for both RCPs and all five GCMs). Both CSMs used four data files for simulation run; (i) weather file with daily solar radiation, maximum and minimum air temperature and precipitation; (ii) soil file of the study area having physical and chemical properties of soil; (iii) crop management file including all input use and application dates; (iv) genetic coefficient file. The detailed information can be found in earlier studies $^{41,79}$. For the analysis, the average crop yields of the farm activities over the time period were also used. For the non-modeled activities (minor crops and milk production) regional representative agricultural pathways (RAPs) were used for the future projections.

\subsection{Economic Modeling}

Economic assessment of climatic change sensitivity was done with the tradeoff analysis model for multidimen- sional impact assessment (TOA-MD) version 6.1 in this study ${ }^{55}-57$. The economic analysis was done on the per farm basis. All farm-based activities; major crops (rice and wheat), minor crops (fodder) and livestock was included for the true representation of the existing socioeconomic conditions of the farming community of the surveyed farms. The analysis was done for both CSMs (APSIM and DSSAT) and both RCPs (RCP 4.5 and RCP 8.5) for each GCM simulation separately.

The model considers farmers as economically rational beings to make decisions on the predictable value and that's why uses binary codes ${ }^{58}$. The farmers may choose to stick to system 1, or they can choose to move to the alternative system 2 . Generally, system 1 is described as the current production system (base technology) with current climate and system 2 as current production system (base technology) with changing climate. The productivity of the system depends largely on two factors technology and climate. Farmers decision making of whether to operate in system 1 or system 2 depends upon the opportunity cost (gains/losses) from switching.

$$
\omega=v_{1}-v_{2}
$$

In Equation 3, $\mathrm{v}_{1}$ and $\mathrm{v}_{2}$ are net returns from System 1 and 2 , respectively.

Poverty line was set US $\$ 1.25 /$ person/day (US $\$ 1=$ PKR 103) in the analysis according to international standards which was to check the vulnerability level of households with respect to climatic changes ${ }^{59}$.

For Climate Change Impact Assessment (CC-IA) analysis all the prices of inputs/outputs were site specific according to the production system(s) and net returns were accordingly.

TOA-MD model parameters for system 1 and 2, for each farm in the survey data in future period, were calculated according to ${ }^{60}$.

$$
\begin{gathered}
\mu_{j}\left(T_{H H}, \gamma_{H}\right)=\beta_{y 0} * y_{j 0} \\
R_{j 21}=\rho_{H} * a_{j H} * \mu_{j}\left(T_{H H}, \gamma_{H}\right) \\
C_{j 21}=\beta_{c 0} * C_{j H} \\
V_{j 21}=R_{j 21}-C_{j 21}
\end{gathered}
$$


Where,

$\Gamma=1, \phi_{\mathrm{H}}=1, \phi_{\mathrm{F}}=1, \psi=1$ for simple CC-IA on current agricultural production system

$$
\begin{gathered}
\mu_{j}\left(T_{H F}, \gamma_{H}\right)=r_{j 2} * \mu_{j}\left(T_{H H}, \gamma_{H}\right) \\
R_{j 22}=\rho_{H} * a_{j H} * \mu_{j}\left(T_{H F}, \gamma_{H}\right) \\
G_{j 22}={ }^{C_{j 22}} / R_{j 22} \\
C_{j 22}=G_{j 22} * R_{j 22} \\
V_{j 22}=R_{j 22}-C_{j 22}
\end{gathered}
$$

\subsubsection{Variables' Definition}

$\mathrm{t} \quad=$ individual year or time period

$\mathrm{H} \quad$ = current time period

$\mathrm{F} \quad=$ future time period

$\mathrm{j}=$ number of farms in data sample used for integrated assessment

$\mathrm{t}=$ the year of data collection

$\square_{\mathrm{ti}} \quad=$ technology and management practices used for period, adapted to climate $(\mathrm{t}, \mathrm{i}=\mathrm{H}$ or $\mathrm{F})$

$\gamma_{\mathrm{jt}} \quad=$ crop yield in year $\mathrm{t}(\mathrm{kg} / \mathrm{ha})$

$\mu_{j}\left(\nabla_{t i}, \gamma_{t}\right)=$ mean yield $(s)$ of farm $j$ using technology $\bigotimes_{t i}$ with climate $\gamma_{\mathrm{t}}$

$\mathrm{Y}_{0} \quad=$ observed mean yield of data

$\mathrm{Y}_{\mathrm{H}} \quad=$ historical mean yields used in current period (secondary data)

$\beta_{\mathrm{y} 0} \quad=\mathrm{Y}_{\mathrm{H}} / \mathrm{Y}_{0}=$ normalization factor of yields $s_{j}\left(\bigotimes_{t i} \gamma_{t}\right)=$ simulated crop yield for farm $j$ using technology $\mathrm{Q}_{\mathrm{ti}}$ with climate $\gamma_{\mathrm{t}}$

$\mathrm{r}_{\mathrm{j}} \quad=$ relative yield for farm $\mathrm{j}$ used for analysis

$\mathrm{a}_{\mathrm{jt}} \quad=$ total crop area on the farm in period $\mathrm{t}(\mathrm{ha})$

$\mathrm{R}_{\mathrm{jt}} \quad=$ revenue $=\mathrm{p}_{\mathrm{t}}{ }^{*} \mathrm{y}_{\mathrm{jt}}{ }^{*} \mathrm{a}_{\mathrm{jt}}$ (rupees per farm per time)

$\mathrm{R}_{\mathrm{js}} \quad=$ net returns in system $\mathrm{s}$ (rupees per farm)

$\mathrm{C}_{\mathrm{jt}}=$ cost of production for period $\mathrm{t}$ (rupees per farm per time)

$\mathrm{C}_{\mathrm{js}} \quad=$ mean cost of production in system $\mathrm{s}$ (rupees per farm)

$\mathrm{C}_{\mathrm{t}}=$ mean cost of production in the current period $(\mathrm{t}=\mathrm{H})$

$\beta_{c 0} \quad=C_{H} / C_{0}=$ normalization factor for production cost (if $\beta_{\mathrm{c}}$ can't be estimated, then use $\beta_{\mathrm{c} 0}=\beta_{\mathrm{y} 0}$ )

$\mathrm{G}_{\mathrm{jt}}=\mathrm{C}_{\mathrm{jt}} / \mathrm{R}_{\mathrm{jt}}=$ production cost relative to revenue (unit free)

$\mathrm{V}_{\mathrm{jt}} \quad=\mathrm{R}_{\mathrm{jt}}-\mathrm{C}_{\mathrm{jt}}=$ crop net returns for the farm (rupees per time)

$\mathrm{V}_{\text {jqs }} \quad=$ time-averaged net returns for part $\mathrm{q}$ and system $s$ (rupees)

RHO12 = correlation between $\mu_{j}\left(\bigotimes_{H H}, \gamma_{\mathrm{F}}\right)$ and $\mu_{j}\left(\bigotimes_{\mathrm{HH}}, \gamma_{\mathrm{H}}\right)$

The TOA-MD incorporated the statistical correlation between environmental, social and economic impacts of technology adoption into the simulation of impacts on NR, PCI and poverty. The model simulates the impacts of the full range of adoption rates from 0 to 100 percent $\frac{61}{}$.

\section{Results}

\subsection{Data Statistics}

The surveyed area in all districts range from 129.66 to 192.31 hectares, smallest in Mandi Bahauddin and largest in Nankana Sahib (Table 1). Likewise, the average land for major crops rice and wheat was dedicated by farmers

Table 1. Mean of farm area for crop activities in the surveyed are according to strata

\begin{tabular}{|l|l|l|l|l|l|}
\hline Stratum/Crops & $\begin{array}{l}\text { Total Farm } \\
\text { Area (ha) }\end{array}$ & $\begin{array}{l}\text { Wheat } \\
\text { cultivated } \\
\text { area (ha) }\end{array}$ & $\begin{array}{l}\text { Rice cultivated } \\
\text { area (ha) }\end{array}$ & $\begin{array}{l}\text { Kharif (Summer) } \\
\text { Fodder Area (ha) }\end{array}$ & $\begin{array}{l}\text { Rabi (Winter) } \\
\text { Fodder Area (ha) }\end{array}$ \\
\hline Sheikhupura & 155.26 & 4.25 & 4.28 & 0.80 & 0.76 \\
\hline Nankana Sahib & 192.31 & 5.18 & 5.33 & 0.87 & 1.02 \\
\hline Hafizabad & 187.04 & 5.04 & 5.08 & 0.99 & 0.99 \\
\hline Gujranwala & 187.45 & 5.05 & 5.04 & 0.99 & 0.99 \\
\hline Sialkot & 166.70 & 4.59 & 4.47 & 0.91 & 0.78 \\
\hline Gujrat & 131.78 & 3.52 & 3.26 & 0.99 & 0.73 \\
\hline Mandi Bahauddin & 129.66 & 3.46 & 3.13 & 1.05 & 0.72 \\
\hline
\end{tabular}


of the study area accordingly, largest in Nankana Sahib and the smallestin Mandi Bahauddin. Wheat area ranged from 3.46 to 5.18 hectares in all study districts, while rice area ranged from 3.13 to 5.33 hectares. For both Rabi and Kharif seasons, the area reserved for fodder crops ranged from 0.72 to 1.02 and 0.80 to 1.05 hectares respectively.

\subsection{Economic Assessment of Climatic Change Sensitivity}

In this section, the isolated climate change impacts were assessed on the prevailing agricultural system. Both major cereal crops, i.e., rice and wheat were modeled and then economic analysis was performed using TOA-MD

Table 2. Climatic change sensitivity impact on economic indicators in district Sheikhupura

\begin{tabular}{|c|c|c|c|c|c|c|}
\hline RCP & CSM & GCM & $\begin{array}{l}\text { Vulnerable } \\
\text { Farm } \\
\text { Household (\%) }\end{array}$ & $\begin{array}{l}\text { NR with } \\
\text { CC (PKR) }\end{array}$ & $\begin{array}{l}\text { PCI with } \\
\text { CC (PKR) }\end{array}$ & $\begin{array}{l}\text { Poverty } \\
\text { with } \\
\text { CC (\%) }\end{array}$ \\
\hline \multirow{10}{*}{4.5} & \multirow{5}{*}{ APSIM } & $\begin{array}{l}\text { Cool } \\
\text { Wet }\end{array}$ & 69.1 & 589,874 & 113,332 & 11.3 \\
\hline & & $\begin{array}{l}\text { Cool } \\
\text { Dry }\end{array}$ & 71.6 & 576,722 & 110,866 & 11.7 \\
\hline & & Middle & 74.6 & 560,377 & 107,802 & 12.1 \\
\hline & & $\begin{array}{l}\text { Hot } \\
\text { Dry }\end{array}$ & 78.1 & 539,421 & 103,872 & 13.1 \\
\hline & & $\begin{array}{l}\text { Hot } \\
\text { Wet }\end{array}$ & 75.6 & 556,146 & 107,008 & 11.4 \\
\hline & \multirow{5}{*}{ DSSAT } & $\begin{array}{l}\text { Cool } \\
\text { Wet }\end{array}$ & 69.0 & 591,709 & 113,676 & 10.6 \\
\hline & & $\begin{array}{l}\text { Cool } \\
\text { Dry }\end{array}$ & 67.8 & 597,383 & 114,740 & 10.6 \\
\hline & & Middle & 73.0 & 570,204 & 109,644 & 11.2 \\
\hline & & $\begin{array}{l}\text { Hot } \\
\text { Dry }\end{array}$ & 78.4 & 539,574 & 103,901 & 11.9 \\
\hline & & $\begin{array}{l}\text { Hot } \\
\text { Wet }\end{array}$ & 77.4 & 545,463 & 105,005 & 11.6 \\
\hline \multirow{10}{*}{8.5} & \multirow{5}{*}{ APSIM } & $\begin{array}{l}\text { Cool } \\
\text { Wet }\end{array}$ & 75.1 & 556,948 & 107,159 & 12.5 \\
\hline & & $\begin{array}{l}\text { Cool } \\
\text { Dry } \\
\end{array}$ & 74.3 & 560,861 & 107,892 & 12.7 \\
\hline & & Middle & 77.4 & 542,829 & 104,511 & 13.3 \\
\hline & & $\begin{array}{l}\text { Hot } \\
\text { Dry }\end{array}$ & 81.5 & 517,434 & 99,750 & 14.2 \\
\hline & & $\begin{array}{l}\text { Hot } \\
\text { Wet }\end{array}$ & 78.8 & 536,749 & 103,371 & 12.2 \\
\hline & \multirow{5}{*}{ DSSAT } & $\begin{array}{l}\text { Cool } \\
\text { Wet }\end{array}$ & 71.6 & 577,999 & 111,105 & 11.0 \\
\hline & & $\begin{array}{l}\text { Cool } \\
\text { Dry } \\
\end{array}$ & 69.3 & 590,274 & 113,407 & 10.7 \\
\hline & & Middle & 76.0 & 553,236 & 106,463 & 11.8 \\
\hline & & $\begin{array}{l}\text { Hot } \\
\text { Dry }\end{array}$ & 80.1 & 528,505 & 101,826 & 12.5 \\
\hline & & $\begin{array}{l}\text { Hot } \\
\text { Wet }\end{array}$ & 79.7 & 531,116 & 102,315 & 12.2 \\
\hline
\end{tabular}


6.0 version. However, the climate vulnerability on minor crops (fodder) and milk production were adjusted according to the GCMs using RAPs. For the clear picture of the analysis, this section is further subdivided into seven subsections explaining the results of Climate Change Impact Assessment (CC-IA) for all strata individually.

\subsubsection{CC-IA for District Sheikhupura}

Results of Sheikhupura shown household vulnerability for RCP 4.5 in all five GCMs in both CSMs i.e., APSIM and DSSAT fluctuated between 69.1 to 78.1 percent and 67.8 to 78.4 percent, respectively. The observed NR and PCI without CC for both RCP 4.5 and RCP 8.5 in all GCMs were PKR 685,357 per farm and PKR 131,235, respectively. However, NR and PCI with CC in RCP 4.5 for APSIM ranged between PKR 539,421 to PKR 589,874 per farm and PKR 103,872 to PKR 110,866 respectively. The NR and PCI with CC for DSSAT varied between
PKR 539,547 to PKR 597,383 per farm and PKR 103,901 to PKR 114,740 respectively. Household vulnerability to climatic changes in RCP 8.5 for all GCMs varied between 74.3 to 81.5 percent for APSIM and 69.3 to 80.1 percent for DSSAT. The NR and PCI with CC for RCP 8.5 ranged from PKR 517,434 to PKR 560,861 per farm and PKR 99,750 to PKR 107,159for APSIM. The NR and PCI with CC for DSSAT varied between PKR 528,505 to PKR 590,274 per farm and PKR 101,826 to PKR 113,407 respectively.

The observed poverty without CC was 8.5 percent, while the poverty with $\mathrm{CC}$ varied according to the effect of climatic conditions on relative yields obtained from both CSMs. In RCP 4.5, poverty fluctuated between 11.3 to 13.1 percent in APSIM and 10.6 to 11.9 percent in DSSAT. However, for RCP 8.5 poverty varied between 12.2 to 14.2 percent in APSIM and 11.0 to 12.5 percent in DSSAT (Table 2).

Table 3. Climatic change sensitivity impact on economic indicators in district Nankana Sahib

\begin{tabular}{|c|c|c|c|c|c|c|}
\hline RCP & $\mathrm{CM}$ & GCM & $\begin{array}{l}\text { Vulnerable } \\
\text { Farm } \\
\text { Household (\%) }\end{array}$ & $\begin{array}{l}\text { NR } \\
\text { with } \\
\text { CC } \\
\end{array}$ & $\begin{array}{l}\text { PCI } \\
\text { with } \\
\text { CC } \\
\end{array}$ & $\begin{array}{l}\text { Poverty } \\
\text { with } \\
\text { CC (\%) }\end{array}$ \\
\hline \multirow{10}{*}{4.5} & \multirow{5}{*}{ APSIM } & Cool Wet & 84.4 & 677,633 & 89,153 & 6.9 \\
\hline & & Cool Dry & 86.0 & 666,498 & 87,712 & 7.0 \\
\hline & & Middle & 87.1 & 658,868 & 86,724 & 7.1 \\
\hline & & Hot Dry & 91.3 & 621,483 & 81,886 & 9.0 \\
\hline & & Hot Wet & 87.8 & 652,053 & 85,842 & 8.1 \\
\hline & \multirow{5}{*}{ DSSAT } & Cool Wet & 80.0 & 705,820 & 92,801 & 5.7 \\
\hline & & Cool Dry & 84.8 & 675,827 & 88,919 & 6.4 \\
\hline & & Middle & 83.2 & 686,386 & 90,286 & 6.2 \\
\hline & & Hot Dry & 87.1 & 659,597 & 86,819 & 6.9 \\
\hline & & Hot Wet & 87.1 & 657,182 & 86,506 & 7.9 \\
\hline \multirow{10}{*}{8.5} & \multirow{5}{*}{ APSIM } & Cool Wet & 88.5 & 645,641 & 85,012 & 8.7 \\
\hline & & Cool Dry & 87.3 & 652,806 & 85,940 & 9.0 \\
\hline & & Middle & 91.9 & 612,762 & 80,757 & 10.4 \\
\hline & & Hot Dry & 91.6 & 615,083 & 81,057 & 10.6 \\
\hline & & Hot Wet & 90.4 & 630,376 & 83,037 & 8.1 \\
\hline & \multirow{5}{*}{ DSSAT } & Cool Wet & 83.1 & 687,308 & 90,405 & 6.2 \\
\hline & & Cool Dry & 86.6 & 662,826 & 87,237 & 7.0 \\
\hline & & Middle & 85.8 & 668,749 & 88,003 & 6.7 \\
\hline & & Hot Dry & 90.0 & 633,909 & 83,494 & 8.3 \\
\hline & & Hot Wet & 88.3 & 646,217 & 85,087 & 8.8 \\
\hline
\end{tabular}




\subsubsection{CC-IA for District Nankana Sahib}

Results of Nankana Sahib shown household vulnerability for RCP 4.5 in all five GCMs in both CSMs i.e., APSIM and DSSAT fluctuated between 84.4 to 91.3 percent and 80.0 to 87.1 percent, respectively. The observed NR and PCI without CC for both RCP 4.5 and RCP 8.5 in all GCMs were PKR 849,040 per farm and PKR 111,338 respectively. However, NR and PCI with CC in RCP 4.5 for APSIM ranged between PKR 621,483 to PKR 677,633 per farm and PKR 81,886 to PKR 89,153 respectively. The NR and PCI with CC for DSSAT varied between PKR 657,182 to PKR 705,820 per farm and PKR 86,506 to PKR 92,801 respectively. Household vulnerability to climatic changes in RCP 8.5 for all GCMs varied between 88.5 to 91.9 percent for APSIM and 83.1 to 90.0 percent for DSSAT. The NR and PCI with CC for RCP 8.5 ranged from PKR 612,762 to PKR 652,806 per farm and PKR 80.757 to PKR 85,940 for APSIM. The NR and PCI with CC for DSSAT varied between PKR 633,909 to PKR 687,308 per farm and PKR 83,494 to PKR 90,405 respectively.
The observed poverty without CC was 3.3 percent, while the poverty with $\mathrm{CC}$ varied according to the effect of climatic conditions on relative yields obtained from both CSMs. In RCP 4.5, poverty fluctuated between 6.9 to 9.0 percent in APSIM and 5.7 to 7.9 percent in DSSAT. However, for RCP 8.5 poverty varied between 8.1 to 10.6 percent in APSIM and 6.2 to 8.8 percent in DSSAT (Table $3)$.

\subsubsection{CC-IA for District Hafizabad}

Results of Hafizabad shown household vulnerability for RCP 4.5 in all five GCMs in both CSMs i.e., APSIM and DSSAT fluctuated between 74.4 to 80.4 percent and 70.4 to 78.0 percent, respectively. The observed NR and PCI without CC for both RCP 4.5 and RCP 8.5 in all GCMs were PKR 746,842 per farm and PKR 183,144 respectively. However, NR and PCI with CC in RCP 4.5 for APSIM ranged between PKR 604,913 to PKR 647,025 per farm and PKR 140,764 to PKR 150,210 respectively. The NR and PCI with CC for DSSAT varied between

Table 4. Climatic change sensitivity impact on economic indicators in district Hafizabad

\begin{tabular}{|c|c|c|c|c|c|c|}
\hline RCP & $\mathrm{CM}$ & GCM & $\begin{array}{l}\text { Vulnerable } \\
\text { Farm } \\
\text { Household (\%) }\end{array}$ & $\begin{array}{l}\text { NR } \\
\text { with } \\
\text { CC } \\
\end{array}$ & $\begin{array}{l}\text { PCI } \\
\text { with } \\
\text { CC } \\
\end{array}$ & $\begin{array}{l}\text { Poverty } \\
\text { with } \\
\text { CC }(\%)\end{array}$ \\
\hline \multirow{10}{*}{4.5} & \multirow{5}{*}{ APSIM } & Cool Wet & 74.4 & 647,025 & 150,210 & 6.8 \\
\hline & & Cool Dry & 75.7 & 638,672 & 148,337 & 6.9 \\
\hline & & Middle & 78.0 & 622,730 & 144,761 & 7.1 \\
\hline & & Hot Dry & 80.4 & 604,913 & 140,764 & 7.5 \\
\hline & & Hot Wet & 79.2 & 613,783 & 142,754 & 7.4 \\
\hline & \multirow{5}{*}{ DSSAT } & Cool Wet & 70.4 & 674,368 & 156,344 & 5.9 \\
\hline & & Cool Dry & 72.2 & 663,109 & 153,818 & 6.1 \\
\hline & & Middle & 74.7 & 646,797 & 150,159 & 6.2 \\
\hline & & Hot Dry & 77.9 & 624,436 & 145,143 & 6.6 \\
\hline & & Hot Wet & 78.0 & 623,376 & 144,906 & 6.8 \\
\hline \multirow{10}{*}{8.5} & \multirow{5}{*}{ APSIM } & Cool Wet & 79.9 & 608,590 & 141,589 & 7.3 \\
\hline & & Cool Dry & 79.5 & 610,236 & 141,958 & 7.8 \\
\hline & & Middle & 82.1 & 590,842 & 137,608 & 8.0 \\
\hline & & Hot Dry & 82.8 & 584,592 & 136,206 & 8.3 \\
\hline & & Hot Wet & 81.5 & 596,136 & 138,795 & 7.8 \\
\hline & \multirow{5}{*}{ DSSAT } & Cool Wet & 72.6 & 660,871 & 153,316 & 6.0 \\
\hline & & Cool Dry & 74.2 & 650,382 & 150,963 & 6.2 \\
\hline & & Middle & 76.2 & 636,540 & 147,858 & 6.6 \\
\hline & & Hot Dry & 79.4 & 613,965 & 142,795 & 6.6 \\
\hline & & Hot Wet & 79.7 & 611,227 & 142,180 & 6.8 \\
\hline
\end{tabular}


Table 5. Climatic change sensitivity impact on economic indicators in district Gujranwala

\begin{tabular}{|c|c|c|c|c|c|c|}
\hline $\mathrm{CM}$ & CC & GCM & $\begin{array}{l}\text { Vulnerable } \\
\text { Farm } \\
\text { Household (\%) }\end{array}$ & $\begin{array}{l}\text { NR with } \\
\text { CC }\end{array}$ & $\begin{array}{l}\text { PCI } \\
\text { with } \\
\text { CC } \\
\end{array}$ & $\begin{array}{l}\text { Poverty } \\
\text { with } \\
\text { CC (\%) }\end{array}$ \\
\hline \multirow{10}{*}{4.5} & \multirow{5}{*}{ APSIM } & $\begin{array}{l}\text { Cool } \\
\text { Wet }\end{array}$ & 68.6 & 639,416 & 66,378 & 23.7 \\
\hline & & $\begin{array}{l}\text { Cool } \\
\text { Dry }\end{array}$ & 70.9 & 627,325 & 65,149 & 23.7 \\
\hline & & Middle & 74.0 & 607,691 & 63,152 & 25.8 \\
\hline & & $\begin{array}{l}\text { Hot } \\
\text { Dry }\end{array}$ & 78.9 & 574,108 & 59,737 & 29.7 \\
\hline & & $\begin{array}{l}\text { Hot } \\
\text { Wet }\end{array}$ & 78.0 & 582,881 & 60,629 & 27.3 \\
\hline & \multirow{5}{*}{ DSSAT } & $\begin{array}{l}\text { Cool } \\
\text { Wet }\end{array}$ & 66.6 & 653,559 & 67,817 & 20.7 \\
\hline & & $\begin{array}{l}\text { Cool } \\
\text { Dry }\end{array}$ & 69.0 & 640,019 & 66,440 & 21.8 \\
\hline & & Middle & 71.3 & 626,129 & 65,027 & 23.0 \\
\hline & & $\begin{array}{l}\text { Hot } \\
\text { Dry }\end{array}$ & 77.2 & 588,987 & 61,250 & 26.2 \\
\hline & & $\begin{array}{l}\text { Hot } \\
\text { Wet }\end{array}$ & 77.5 & 586,160 & 60,962 & 27.2 \\
\hline \multirow{10}{*}{8.5} & \multirow{5}{*}{ APSIM } & $\begin{array}{l}\text { Cool } \\
\text { Wet }\end{array}$ & 75.5 & 594,450 & 61,806 & 28.4 \\
\hline & & $\begin{array}{l}\text { Cool } \\
\text { Dry }\end{array}$ & 75.9 & 592,525 & 61,610 & 28.4 \\
\hline & & Middle & 78.2 & 576,605 & 59,991 & 30.1 \\
\hline & & $\begin{array}{l}\text { Hot } \\
\text { Dry }\end{array}$ & 79.7 & 567,643 & 59,079 & 30.6 \\
\hline & & $\begin{array}{l}\text { Hot } \\
\text { Wet }\end{array}$ & 80.4 & 564,736 & 58,784 & 30.1 \\
\hline & \multirow{5}{*}{ DSSAT } & $\begin{array}{l}\text { Cool } \\
\text { Wet }\end{array}$ & 68.7 & 641,906 & 66,632 & 21.5 \\
\hline & & $\begin{array}{l}\text { Cool } \\
\text { Dry }\end{array}$ & 70.2 & 632,771 & 65,703 & 22.4 \\
\hline & & Middle & 73.2 & 614,860 & 63,881 & 23.7 \\
\hline & & $\begin{array}{l}\text { Hot } \\
\text { Dry }\end{array}$ & 77.9 & 584,097 & 60,753 & 26.6 \\
\hline & & $\begin{array}{l}\text { Hot } \\
\text { Wet }\end{array}$ & 79.6 & 571,135 & 59,435 & 28.7 \\
\hline
\end{tabular}

PKR 623,376 to PKR 674,368 per farm and PKR 144,906 to PKR 156,344 respectively. Household vulnerability to climatic changes in RCP 8.5 for all GCMs varied between 79.5 to 82.8 percent for APSIM and 72.6 to 79.7 percent for DSSAT. The NR and PCI with CC for RCP
8.5 ranged from PKR 584,592 to PKR 610,236 per farm and PKR 136,206 to PKR 141,958for APSIM. The NR and PCI with CC for DSSAT varied between PKR 611,227 to PKR 660,871 per farm and PKR 142,180 to PKR 153,963 respectively. 
The observed poverty without CC was 5.0 percent, while the poverty with $\mathrm{CC}$ varied according to the effect of climatic conditions on relative yields obtained from both CSMs. In RCP 4.5, poverty fluctuated between 6.8 to 7.5 percent in APSIM and 5.9 to 6.8 percent in DSSAT. However, for RCP 8.5 poverty varied between 7.3 to 8.3 percent in APSIM and 6.0 to 6.8 percent in DSSAT (Table 4).

\subsubsection{CC-IA for District Gujranwala}

Results of Gujranwala shown household vulnerability for RCP 4.5 in all five GCMs in both CSMs i.e., APSIM and DSSAT fluctuated between 68.6 to 78.9 percent and 66.6 to 77.5percent, respectively. The observed NR and PCI without CC for both RCP 4.5 and RCP 8.5 in all GCMs were PKR 746,500 per farm and PKR 77,269 respectively. However, NR and PCI with CC in RCP 4.5 for APSIM ranged between PKR 574,108 to PKR 639,416 per farm and PKR 59,737 to PKR 66,378 respectively. The NR and PCI with CC for DSSAT varied between PKR 586,160 to PKR 653,559 per farm and PKR 60,962 to PKR 67,817 respectively. Household vulnerability to climatic changes in RCP 8.5 for all GCMs varied between 75.5 to 80.4 percent for APSIM and 68.7 to 79.6 percent for DSSAT. The NR and PCI with CC for RCP 8.5 ranged from PKR 564,736 to PKR 594,450 per farm and PKR 58,784 to PKR 61,806 for APSIM. The NR and PCI with CC for DSSAT varied between PKR 571,135 to PKR 641,906 per farm and PKR 59,435 to PKR 66,632 respectively.

The observed poverty without CC was 15.4 percent, while the poverty with CC varied according to the effect of climatic conditions on relative yields obtained of both CSMs. In RCP 4.5, poverty fluctuated between 23.7 to 29.7 percent in APSIM and 20.7 to 27.2 percent in DSSAT. However, for RCP 8.5 poverty varied between 28.4 to 30.6percent in APSIM and 21.5 to 28.7 percent in DSSAT (Table 5).

\subsubsection{CC-IA for District Sialkot}

Results of Sialkot shown household vulnerability for RCP 4.5 in all five GCMs in both CSMs i.e., APSIM and DSSAT fluctuated between 79.0 to 86.4 percent and 72.0

Table 6. Climatic change sensitivity impact on economic indicators in district Sialkot

\begin{tabular}{|c|c|c|c|c|c|c|}
\hline $\mathrm{RCP}$ & $\mathrm{CM}$ & GCM & $\begin{array}{l}\text { Vulnerable Farm } \\
\text { Household (\%) }\end{array}$ & $\begin{array}{l}\text { NR with } \\
\text { CC }\end{array}$ & $\begin{array}{l}\text { PCI } \\
\text { with CC }\end{array}$ & $\begin{array}{l}\text { Poverty with } \\
\text { CC (\%) }\end{array}$ \\
\hline \multirow{10}{*}{4.5} & \multirow{5}{*}{ APSIM } & Cool Wet & 79.0 & 495,181 & 66,660 & 24.5 \\
\hline & & Cool Dry & 81.5 & 478,806 & 64,530 & 26.3 \\
\hline & & Middle & 82.7 & 471,234 & 63,545 & 26.7 \\
\hline & & Hot Dry & 86.4 & 442,097 & 59,755 & 30.0 \\
\hline & & Hot Wet & 84.7 & 456,023 & 61,567 & 28.5 \\
\hline & \multirow{5}{*}{ DSSAT } & Cool Wet & 72.0 & 534,454 & 71,769 & 21.6 \\
\hline & & Cool Dry & 80.9 & 483,432 & 65,132 & 25.1 \\
\hline & & Middle & 80.3 & 487,179 & 65,619 & 24.6 \\
\hline & & Hot Dry & 84.2 & 459,824 & 62,061 & 28.1 \\
\hline & & Hot Wet & 85.3 & 451,347 & 60,958 & 29.6 \\
\hline \multirow{10}{*}{8.5} & \multirow{5}{*}{ APSIM } & Cool Wet & 87.9 & 428,388 & 57,972 & 31.7 \\
\hline & & Cool Dry & 82.5 & 472,485 & 63,708 & 26.4 \\
\hline & & Middle & 87.4 & 433,179 & 58,595 & 31.1 \\
\hline & & Hot Dry & 88.2 & 426,186 & 57,686 & 32.3 \\
\hline & & Hot Wet & 85.9 & 445,970 & 60,259 & 31.2 \\
\hline & \multirow{5}{*}{ DSSAT } & Cool Wet & 74.9 & 519,316 & 69,800 & 22.2 \\
\hline & & Cool Dry & 81.7 & 478,091 & 64,437 & 25.8 \\
\hline & & Middle & 82.0 & 475,973 & 64,162 & 25.9 \\
\hline & & Hot Dry & 85.4 & 450,241 & 60,815 & 29.3 \\
\hline & & Hot Wet & 86.3 & 443,429 & 59,929 & 30.3 \\
\hline
\end{tabular}


to 85.3 percent, respectively. The observed NR and PCI without CC for both RCP 4.5 and RCP 8.5 in all GCMs were PKR 642,014per farm and PKR 85,760 respectively. However, NR and PCI with CC in RCP 4.5 for APSIM ranged between PKR 442,097to PKR 495,181 per farm and PKR 59,755 to PKR 66,660 respectively. The NR and PCI with CC for DSSAT varied between PKR 451,347 to PKR 534,454per farm and PKR 60,958 to PKR 71,769 respectively. Household vulnerability to climatic changes in RCP 8.5 for all GCMs varied between82.5 to 88.2 percent for APSIM and 74.9 to 86.3 percent for DSSAT. The NR and PCI with CC for RCP 8.5 ranged from PKR
426,186 to PKR 472,485 per farm and PKR 57,686 to PKR 63,708 for APSIM. The NR and PCI with CC for DSSAT varied between PKR 443,429 to PKR 519,316 per farm and PKR 59,929 to PKR 69,800 respectively.

The observed poverty without CC was 14.7 percent, while the poverty with CC varied according to the effect of climatic conditions on relative yields obtained from both CSMs. In RCP 4.5, poverty fluctuated between 24.5 to 30.0percent in APSIM and 21.6 to 29.6 percent in DSSAT. However, for RCP 8.5 poverty varied between 26.4 to 32.3 percent in APSIM and 22.2 to 30.3 percent in DSSAT (Table 6).

Table 7. Climatic change sensitivity impact on economic indicators in district Gujrat

\begin{tabular}{|c|c|c|c|c|c|c|}
\hline $\mathrm{RCP}$ & $\mathrm{CM}$ & GCM & $\begin{array}{l}\text { Vulnerable Farm } \\
\text { Household (\%) }\end{array}$ & $\begin{array}{l}\text { NR with } \\
\text { CC }\end{array}$ & $\begin{array}{l}\text { PCI } \\
\text { with } \\
\text { CC }\end{array}$ & $\begin{array}{l}\text { Poverty } \\
\text { with CC } \\
\text { (\%) }\end{array}$ \\
\hline \multirow{10}{*}{4.5} & \multirow{5}{*}{ APSIM } & $\begin{array}{l}\text { Cool } \\
\text { Wet }\end{array}$ & 74.3 & 382,099 & 75,467 & 18.9 \\
\hline & & $\begin{array}{l}\text { Cool } \\
\text { Dry }\end{array}$ & 75.3 & 378,713 & 74,832 & 18.8 \\
\hline & & Middle & 77.5 & 370,507 & 73,294 & 20.0 \\
\hline & & Hot Dry & 80.8 & 356,706 & 70,706 & 22.2 \\
\hline & & Hot Wet & 80.0 & 360,774 & 71,469 & 21.0 \\
\hline & \multirow{5}{*}{ DSSAT } & $\begin{array}{l}\text { Cool } \\
\text { Wet }\end{array}$ & 68.5 & 401,995 & 79,197 & 16.9 \\
\hline & & $\begin{array}{l}\text { Cool } \\
\text { Dry }\end{array}$ & 72.7 & 388,047 & 76,582 & 18.0 \\
\hline & & Middle & 74.3 & 382,530 & 75,548 & 18.5 \\
\hline & & Hot Dry & 78.6 & 366,122 & 72,471 & 20.4 \\
\hline & & Hot Wet & 78.3 & 367,081 & 72,651 & 20.9 \\
\hline \multirow{10}{*}{8.5} & \multirow{5}{*}{ APSIM } & $\begin{array}{l}\text { Cool } \\
\text { Wet }\end{array}$ & 77.9 & 368,627 & 72,941 & 20.4 \\
\hline & & $\begin{array}{l}\text { Cool } \\
\text { Dry } \\
\end{array}$ & 77.4 & 370,500 & 73,292 & 20.4 \\
\hline & & Middle & 80.8 & 357,181 & 70,795 & 21.6 \\
\hline & & Hot Dry & 82.7 & 348,798 & 69,223 & 23.1 \\
\hline & & Hot Wet & 83.2 & 346,812 & 68,851 & 22.6 \\
\hline & \multirow{5}{*}{ DSSAT } & $\begin{array}{l}\text { Cool } \\
\text { Wet }\end{array}$ & 72.3 & 389,498 & 76,854 & 17.9 \\
\hline & & $\begin{array}{l}\text { Cool } \\
\text { Dry } \\
\end{array}$ & 75.2 & 379,159 & 74,916 & 18.9 \\
\hline & & Middle & 76.1 & 376,084 & 74,339 & 19.0 \\
\hline & & Hot Dry & 79.3 & 363,588 & 71,996 & 20.8 \\
\hline & & Hot Wet & 80.0 & 360,426 & 71,403 & 21.5 \\
\hline
\end{tabular}




\subsubsection{CC-IA for District Gujrat}

Results of Gujrat shown household vulnerability for RCP 4.5 in all five GCMs in both CSMs i.e., APSIM and DSSAT fluctuated between 74.3 to 80.8 percent and 68.5 to 78.6 percent, respectively. The observed NR and PCI without CC for both RCP 4.5 and RCP 8.5 in all GCMs were PKR 458,260 per farm and PKR 89,747 respectively. However, NR and PCI with CC in RCP 4.5 for APSIM ranged between PKR 356,706 to PKR 382,099 per farm and PKR 70,706 to PKR 75,467 respectively. The NR and PCI with CC for DSSAT varied between PKR 366,122 to PKR 401,995 per farm and PKR 72,471 to PKR 79,197 respectively. Household vulnerability to climatic changes in RCP 8.5 for all GCMs varied between77.4 to 83.2 percent for APSIM and 72.3 to 80.0 percent for DSSAT. The NR and PCI with CC for RCP 8.5 ranged from PKR 346,812 to PKR 370,500 per farm and PKR 68,851 to PKR 73,292 for APSIM. The NR and PCI with CC for DSSAT varied between PKR 360,426 to PKR 389,498 per farm and PKR 71,403 to PKR 76,854 respectively.
The observed poverty without CC was 14.0 percent, while the poverty with $\mathrm{CC}$ varied according to the effect of climatic conditions on relative yields obtained from both CSMs. In RCP 4.5, poverty fluctuated between 18.8 to 22.2 percent in APSIM and 16.9 to 20.9 percent in DSSAT. However, for RCP 8.5 poverty varied between 20.4 to 23.1 percent in APSIM and 17.9 to 21.5percent in DSSAT (Table 7).

\subsubsection{CC-IA for District Mandi Bahauddin}

Results of Mandi Bahauddin shown household vulnerability for RCP 4.5 in all five GCMs in both CSMs i.e., APSIM and DSSAT fluctuated between 75.1 to 85.3 percent and 68.2 to 81.5 percent, respectively. The observed NR and PCI without CC for both RCP 4.5 and RCP 8.5 in all GCMs were PKR 484,645 per farm and PKR 111,398 respectively. However, NR and PCI with CC in RCP 4.5 for APSIM ranged between PKR 381,630 to PKR 417,434 per farm and PKR 88,474 to PKR 96,442 respectively. The NR and PCI with CC for DSSAT varied between PKR

Table 8. Climatic change sensitivity impact on economic indicators in district Mandi Bahauddin

\begin{tabular}{|c|c|c|c|c|c|c|}
\hline $\mathrm{RCP}$ & $\mathrm{CM}$ & GCM & $\begin{array}{l}\text { Vulnerable Farm } \\
\text { Household (\%) }\end{array}$ & $\begin{array}{l}\text { NR } \\
\text { with } \\
\mathrm{CC} \\
\end{array}$ & $\begin{array}{l}\text { PCI } \\
\text { with } \\
\text { CC }\end{array}$ & $\begin{array}{l}\text { Poverty } \\
\text { with } \\
\text { CC (\%) }\end{array}$ \\
\hline \multirow{10}{*}{4.5} & \multirow{5}{*}{ APSIM } & Cool Wet & 75.1 & 417,434 & 96,442 & 9.5 \\
\hline & & Cool Dry & 79.3 & 404,262 & \begin{tabular}{|l|}
93,510 \\
\end{tabular} & 10.0 \\
\hline & & Middle & 80.5 & 399,949 & 92,550 & 10.4 \\
\hline & & Hot Dry & 85.3 & 381,630 & 88,474 & 11.8 \\
\hline & & Hot Wet & 82.6 & 391,657 & 90,705 & 11.4 \\
\hline & \multirow{5}{*}{ DSSAT } & Cool Wet & 68.2 & 437,356 & 100,875 & 8.6 \\
\hline & & Cool Dry & 71.6 & 427,833 & 98,756 & 9.1 \\
\hline & & Middle & 77.5 & 409,901 & 94,765 & 9.9 \\
\hline & & Hot Dry & 81.5 & 396,355 & 91,751 & 10.7 \\
\hline & & Hot Wet & 81.3 & 397,143 & 91,926 & 10.5 \\
\hline \multirow{10}{*}{8.5} & \multirow{5}{*}{ APSIM } & Cool Wet & 82.2 & 393,982 & 91,223 & 10.7 \\
\hline & & Cool Dry & 80.8 & 398,828 & 92,301 & 10.5 \\
\hline & & Middle & 84.0 & 386,853 & 89,636 & 11.2 \\
\hline & & Hot Dry & 88.4 & 367,199 & 85,263 & 13.2 \\
\hline & & Hot Wet & 85.7 & 379,102 & 87,912 & 12.5 \\
\hline & \multirow{5}{*}{ DSSAT } & Cool Wet & 71.0 & 429,628 & 99,155 & 8.9 \\
\hline & & Cool Dry & 72.4 & 425,371 & 98,208 & 9.2 \\
\hline & & Middle & 78.7 & 405,920 & 93,879 & 10.2 \\
\hline & & Hot Dry & 84.5 & 385,057 & 89,237 & 10.9 \\
\hline & & Hot Wet & 86.3 & 377,468 & 87,548 & 11.7 \\
\hline
\end{tabular}


396,355 to PKR 437,356 per farm and PKR 91,751 to PKR 100,875 respectively. Household vulnerability to climatic changes in RCP 8.5 for all GCMs varied between 80.8 to 88.4 percent for APSIM and 71.0 to 86.3 percent for DSSAT. The NR and PCI with CC for RCP 8.5 ranged from PKR 367,199 to PKR 398,828 per farm and PKR85,263 to PKR 92,301 for APSIM. The NR and PCI with CC for DSSAT varied between PKR 385,057 to PKR 429,628 per farm and PKR 87,548 to PKR 99,155 respectively.

The observed poverty without CC was 7.2 percent, while the poverty with $\mathrm{CC}$ varied according to the effect of climatic conditions on relative yields obtained from both CSMs. In RCP 4.5, poverty fluctuated between 9.5 to 11.8 percent in APSIM and 8.6 to 10.7 percent in DSSAT. However, for RCP 8.5 poverty varied between 10.5 to 13.2 percent in APSIM and 8.9 to 11.7 percent in DSSAT (Table 8).

\section{Discussion}

Most of the developing countries in the world are dependent on agriculture for the livelihood needs of its farmhands. The impacts of climate change are mostly negative in the case of the agricultural sector. Therefore, it is very important to predict these impacts on the farming community which can be dealt with economic modeling. This study is innovative in this way, as it uses an integrated approach of climate, crop, and economic modeling. In the case of Pakistan, it is in the pioneers of using such an integrated approach.

The crop modeling results of the study used for economic modelling that is relative yields show that there are negative impacts of climate change on the yields of both major cereal crops of the country i.e., rice and wheat for all GCMs and RCPs ${ }^{41,63}$. The results indicated that percentage losses were higher in RCP 8.5 as compared to RCP 4.5 for both CSMs. The comparison of both CSMs given the insight that the percent losses were higher in APSIM as compared to DSSAT, and DSSAT showed more gains. The empirical net impact of climate change was observed negative for both RCPs and CSMs in all districts.

The findings of the three main economic factors (NR per farm, PCI and poverty) depicted that the overall impact of climate change is negative for both RCPs and CSMs. The net returns per farm and per capita income shown the declining trend for both RCPs and CSMs, however, the intensity was higher in RCP 8.5 in comparison to RCP 4.5. Likewise, the poverty status was higher in RCP 8.5 (harsh climatic conditions) as compared to RCP 4.5 (mild climatic conditions) in both CSMs. The findings of the study re-endorsed the fact that climatic variations especially temperature and precipitation negatively affect the yields of both crops which in turn reduced net returns per farm, per capita income, and poverty rates ${ }^{66,67}$. Presently, Pakistan has very low adaptive capacity to climate change due to lack of extension services, infrastructure, required information to formulate and implement effective policy measures ${ }^{3}$. Therefore, the results of this study will act as a way forward in the formulation of current and future adaptation strategies.

The reduction in wheat productivity due to climatic factors is also evident from several other studies in Pakistan ${ }^{3,66,67}$. The decline in rice yield is also observed in this study. But there is less published literature on the impact of climate change on rice in Pakistan ${ }^{37,63}$. Naqvi, Asif $\underline{63}$ done a similar study in the rice-wheat zone of Punjab, Pakistan. But there were some limitations of that study which we have tried to incorporate. First, we took the whole RWCS and data was collected from all seven districts making the sample size most heterogeneous. Second, Naqvi, Asif $\underline{\underline{6} 3}$ took only the rice-wheat crops in making the agricultural system, but this study used all farm-based activities; rice, wheat, minor fodder crops, and livestock. Therefore, the results of climate change impact assessment are clearly observed on the socioeconomic variables of the respondents because almost all sub-sections of agricultural income were considered in this study.

\section{Conclusions}

The socioeconomic conditions of farmers are vulnerable to both climatic and non-climatic risks in agriculture. The objective of this study was to measure the impact of climatic risks on currently integrated rice-wheat cropping zone of Pakistan considering both mild and harsh representative concentration pathways, i.e., RCP 4.5 and 8.5 using APSIM and DSSAT crop models. The climatic modelling reaffirmed the fact of increase in temperature for the study area. This increase in temperature resulted a decline in the relative yields for both CSMs of modeled activities (rice and wheat). The study concluded that the net economic impacts of climate change are negative for both RCPs and CSMs in the study area. The poverty of the study area will rise with climate change and it is more prominent while using RCP 8.5 as compared with RCP 
4.5 in both crop simulation models. The highest increase in poverty was observed using APSIM crop model for hot-dry conditions. The study suggested that there is a dire need of adaptations strategies and to update agronomic practices to address the adverse impacts of climate risks and to ensure food security and livelihood of the people relying on agriculture in the study area. Therefore, the need of the hour is to put serious efforts in this aspect with a particular focus on the agricultural system at regional and national levels.

\section{Acknowledgement}

This study is the part of first author's (TH) doctoral dissertation. Authors' would like to acknowledge the Agricultural Model for Inter comparison and Improvement Project (AgMIP), global and Pakistan for providing the logistic and technical support to conduct this study. Authors' would also like to acknowledge the farmers and the data collection team for their time to be valued.

\section{References}

1. Bhattacharya A. Chapter 1 - Global Climate Change and Its Impact on Agriculture. Changing Climate andResource Use Efficiency in Plants: Academic Press; 2019; 1-50. https:// doi.org/10.1016/B978-0-12-816209-5.00001-5.

2. Kiesel J, Guse B, Bormann H. Chapter 16 - Projecting the Consequences of Climate Change on River Ecosystems. Multiple Stressors in River Ecosystems: Elsevier; 2019; 281301. https://doi.org/10.1016/B978-0-12-811713-2.00016-9.

3. Abid M, Schneider UA, Scheffran J. Adaptation to climate change and its impacts on food productivity and crop income: Perspectives of farmers in rural Pakistan. J. Rural Stud. 2016; 47: 254-66. https://doi.org/10.1016/j. jrurstud.2016.08.005.

4. Thornton PK, Ericksen PJ, Herrero M, Challinor AJ. Climate variability and vulnerability to climate change: a review. Glob Chang Biol. 2014; 20(11): 3313-28. https:// doi.org/10.1111/gcb.12581.

5. Fahad S, Hussain S, Saud S, Hassan S, Ihsan Z, Shah AN, et al. Exogenously Applied Plant Growth Regulators Enhance the Morpho-Physiological Growth and Yield of Rice under High Temperature. Front Plant Sci. 2016; 7: 1250. https:// doi.org/10.3389/fpls.2016.01250.

6. Adger WN, Huq S, Brown K, Conway D, Hulme M. Adaptation to climate change in the developing world. Progress in Development Studies. 2003; 3(3): 179-95. https://doi.org/10.1191/1464993403ps060oa.
7. Fahad S, Hussain S, Saud S, Hassan S, Tanveer M, Ihsan $\mathrm{MZ}$, et al. A combined application of biochar and phosphorus alleviates heat-induced adversities on physiological, agronomical and quality attributes of rice. Plant Physiology Biochemistry. 2016; 103: 191-8. https://doi.org/10.1016/j. plaphy.2016.03.001.

8. Solomon S, Qin D, Manning M, Chen Z, Marquis M, Averyt K, et al. Climate change 2007: The Physical Science Basis: Contribution of Working Group I to the Fourth Assessment Report of the Intergovernmental Panel on Climate Change, 2007: Cambridge University Press for the intergovernmental Panel on Climate Change, Cambridge; 2007.

9. Solomon S, Plattner G-K, Knutti R, Friedlingstein P. Irreversible climate change due to carbon dioxide emissions. Proceedings of the national academy of sciences. 2009; 106(6): 1704-9. https://doi.org/10.1073/pnas.0812721106.

10. Kurukulasuriya $P$, Rosenthal S. Climate change and agriculture: A review of impacts and adaptations. Washington, DC.: World Bank; 2013.

11. Cline WR. Global warming and agriculture: End-ofcentury estimates by country: Peterson Institute; 2007.

12. Leal-Filho W. Progress with climate change management in the Asia Pacific region. International Journal of Climate Change Strategies and Management. 2015; 7(2). https://doi. org/10.1108/IJCCSM-02-2015-0019.

13. Porter JR, Xie L, Challinor AJ, Cochrane K, Howden SM, Iqbal MM, et al. Food security and food production systems. United Kingdom: Cambridge university press, Cambridge; 2014. Report No.: 1107058074.

14. Trapp N. The Economic Impacts of Climate Change and Options for Adaptation: A Study of the Farming Sector in the European Union. Germany: Universität Hamburg: Wirtschaftswissenschaften; 2014.

15. Lobell DB, Hammer GL, McLean G, Messina C, Roberts MJ, Schlenker W. The critical role of extreme heat for maize production in the United States. Nature Climate Change. 2013; 3(5): 497. https://doi.org/10.1038/nclimate1832.

16. Phalkey RK, Aranda-Jan C, Marx S, Höfle B, Sauerborn R. Systematic review of current efforts to quantify the impacts of climate change on undernutrition. Proceedings of the National Academy of Sciences. 2015; 112(33): E4522-E9. https://doi.org/10.1073/pnas.1409769112.

17. Haile B, Signorelli S, Azzarri C, Johnson T. Welfare effects of weather variability: Multi-country evidence from Africa south of the Sahara. PloS one. 2018; 13(11): e0206415. https://doi.org/10.1371/journal.pone.0206415.

18. Harvey CA, Rakotobe ZL, Rao NS, Dave R, Razafimahatratra $\mathrm{H}$, Rabarijohn $\mathrm{RH}$, et al. Extreme vulnerability of smallholder farmers to agricultural risks and climate change in Madagascar. Philosophical Transactions of the Royal Society A: Mathematical, Physical Engineering Sciences. 
2014; 369(1639): 20130089. https://doi.org/10.1098/ rstb.2013.0089.

19. Schlenker W, Lobell DB. Robust negative impacts of climate change on african agriculture. Environmental Research Letters. 2010; 5(1): 014010. https://doi.org/10.1088/17489326/5/1/014010.

20. Rowhani P, Lobell DB, Linderman M, Ramankutty N. Climate variability and crop production in Tanzania. Agricultural Forest Meteorology. 2011; 151(4): 449-60. https://doi.org/10.1016/j.agrformet.2010.12.002.

21. Lybbert TJ, Sumner DA. Agricultural technologies for climate change in developing countries: Policy options for innovation and technology diffusion. Food Policy. 2012; 37(1): 114-23. https://doi.org/10.1016/j.foodpol.2011.11.001.

22. Jarvis A, Ramirez-Villegas J, Campo BVH, Navarro-Racines C. Is cassava the answer to African climate change adaptation? Tropical Plant Biology. 2012; 5(1): 9-29. https://doi. org/10.1007/s12042-012-9096-7.

23. Waha K, Müller C, Bondeau A, Dietrich J, Kurukulasuriya $\mathrm{P}$, Heinke J, et al. Adaptation to climate change through the choice of cropping system and sowing date in sub-Saharan Africa. Global Environmental Change. 2013; 23(1): 130-43. https://doi.org/10.1016/j.gloenvcha.2012.11.001.

24. Rosenzweig C, Parry ML. Potential impact of climate change on world food supply. Nature. 1994; 367(6459): 133-8. https://doi.org/10.1038/367133a0.

25. Parry M, Rosenzweig C, Livermore M. Climate change, global food supply and risk of hunger. Philosophical Transactions of the Royal Society of London B: Biological Sciences. 2005; 360(1463): 2125-38. https://doi. org/10.1098/rstb.2005.1751.

26. Kabubo-Mariara J, Karanja FK. The economic impact of climate change on Kenyan crop agriculture: A Ricardian approach: The World Bank; 2007. https://doi. org/10.1596/1813-9450-4334.

27. Hisali E, Kasirye I. Review of agricultural sector investments and institutional performance, final report submitted to the Poverty Monitoring and Analysis Unit of the Ministry of Finance Planning and Economic Development (MFPED) 2008.

28. Liu J, Rasul G. Climate change, the Himalayan mountains, and ICIMOD. Sustainable Mountain Development. 2007; 53: 11-4.

29. Lobell DB, Burke MB, Tebaldi C, Mastrandrea MD, Falcon WP, Naylor RL. Prioritizing climate change adaptation needs for food security in 2030. Science. 2008; 319(5863): 607-10. https://doi.org/10.1126/science.1152339.

30. Barros V, Field C, Dokke D, Mastrandrea M, Mach $\mathrm{K}$, Bilir TE, et al. Climate change 2014: impacts, adaptation, and vulnerability-Part B: regional aspectsContribution of Working Group II to the Fifth Assessment
Report of the Intergovernmental Panel on Climate Change. Intergovernmental Panel on Climate Change (IPCC). Geneva, Switzerland; 2014.

31. IUCN. Climate Change; Vulnerabilities in Agriculture in Pakistan. 2009.

32. Kreft S, Eckstein D, Junghans L, Kerestan C, Hagen U. Global climate risk index 2014. 2013.

33. Eckstein D, Künzel V, Schäfer L. Global climate risk index 2018. J Germanwatch, Bonn. 2017.

34. Parry M, Parry ML, Canziani O, Palutikof J, Van der Linden P, Hanson C. Climate change 2007-impacts, adaptation and vulnerability: Working group II contribution to the fourth assessment report of the IPCC: Cambridge University Press; 2007.

35. Lal M. Implications of climate change in sustained agricultural productivity in South Asia. Regional Environmental Change. 2011; 11(1): 79-94. https://doi.org/10.1007/ s10113-010-0166-9.

36. Hanif U, Syed SH, Ahmad R, Malik KA, Nasir M. Economic Impact of Climate Change on the Agricultural Sector of Punjab [with Comments]. The Pakistan Development Review. 2010; 49(4): 771-98. https://doi.org/10.30541/ v49i4IIpp.771-798.

37. Arshad M, Amjath-Babu T, Krupnik TJ, Aravindakshan S, Abbas A, Kächele H, et al. Climate variability and yield risk in South Asia's rice-wheat systems: emerging evidence from Pakistan. Paddy Water Environment. 2017; 15(2): 249-61. https://doi.org/10.1007/s10333-016-0544-0.

38. Sultana H, Ali N, editors. Vulnerability of wheat production in different climatic zones of Pakistan under climate change scenarios using CSM-CERES-Wheat Model. Second International Young Scientists' Global Change Conference, Beijing; 2006.

39. Hussain A, Bashir A, Anwar MZ, Mehmood I. Agricultural productivity and rural poverty in the rice-wheat and mixedcropping zones of the Punjab. Pakistan journal of Life and Social Sciences. 2011; 9(2): 172-8.

40. Hussain SS, Mudasser M. Prospects for wheat production under changing climate in mountain areas of Pakistan - An econometric analysis. Agricultural Systems. 2007; 94: 494501. https://doi.org/10.1016/j.agsy.2006.12.001.

41. Ahmad A, Ashfaq M, Rasul G, Wajid SA, Khaliq T, Rasul $F$, et al. Impact of climate change on the rice-wheat cropping system of Pakistan. Handbook of Climate Change and Agroecosystems: The Agricultural Model Intercomparison and Improvement Project Integrated Crop and Economic Assessments, Part 2: World Scientific; 2015; 219-58. https:// doi.org/10.1142/9781783265640_0019.

42. Ahmad M, Iqbal M, Khan M. Climate change, agriculture and food security in Pakistan: adaptation options and strategies. Pakistan Institute of Development Economics. Islamabad, Pakistan.; 2013. 
43. MOE-GIRP. Pakistan's initial national communication on climate change. Government of Islamic Republic of Pakistan, Ministry of Environment, Islamabad-Pakistan, November.; 2003.

44. Hii YL, Rocklöv J, Ng N, Tang CS, Pang FY, Sauerborn R. Climate variability and increase in intensity and magnitude of dengue incidence in Singapore. Global Health Action. 2009; 2(1). https://doi.org/10.3402/gha.v2i0.2036.

45. Asseng S, Foster I, Turner NC. The impact of temperature variability on wheat yields. Global Change Biology. 2011; 17(2): 997-1012. https://doi.org/10.1111/j.13652486.2010.02262.x.

46. Reynolds MP, Balota M, Delgado M, Amani I, Fischer R. Physiological and Morphological Traits Associated with Spring Wheat Yield Under Hot, Irrigated Conditions. Aust. J. Plant Physiol. 1994; 21(6): 717. https://doi.org/10.1071/ PP9940717.

47. David BL, Adam S, Ortiz-Monasterio JI. Extreme heat effects on wheat senescence in India. Nature Climate Change. 2012; 2(3): 186. https://doi.org/10.1038/nclimate1356.

48. Shah F, Huang J, Cui K, Nie L, Shah T, Chen C, et al. Impact of high-temperature stress on rice plant and its traits related to tolerance. The J. Agric. Sci.. 2011; 149(5): 545-56. https:// doi.org/10.1017/S0021859611000360.

49. Krishnan P, Ramakrishnan B, Reddy KR, Reddy VR. High-Temperature Effects on Rice Growth, Yield, and Grain Quality. High-Temperature Effects on Rice Growth, Yield, and Grain Quality. 2011; 111: 87-206. https://doi. org/10.1016/B978-0-12-387689-8.00004-7.

50. Reynolds MP, Quilligan E, Aggarwal PK, Bansal KC, Cavalieri AJ, Chapman SC, et al. An integrated approach to maintaining cereal productivity under climate change. Global Food Security. 2016; 8: 9-18. https://doi. org/10.1016/j.gfs.2016.02.002.

51. Kunimitsu Y, Iizumi T, Yokozawa M. Is long-term climate change beneficial or harmful for rice total factor productivity in Japan: evidence from a panel data analysis.(Report). Paddy and Water Environment. 2014; 12(2) :213. https:// doi.org/10.1007/s10333-013-0368-0.

52. Wassmann R, Jagadish S, Heuer S, Ismail A, Redona E, Serraj $\mathrm{R}$, et al. Climate change affecting rice production: the physiological and agronomic basis for possible adaptation strategies. Advances in agronomy. 2009; 101: 59-122. https://doi.org/10.1016/S0065-2113(08)00802-X.

53. Sarker MAR, Alam K, Gow J. Exploring the relationship between climate change and rice yield in Bangladesh: An analysis of time series data. Agricultural Systems. 2012; 112(C): 11-6. https://doi.org/10.1016/j.agsy.2012.06.004.

54. Iqbal MM, editor Climate change impacts on agriculture and building resilience in Pakistan. Workshop on develop- ing farming system for climate change mitigation, Colombo Sri Lanka http://www adbi org/files/201308; 2013.

55. Timsina J, Connor DJ. Productivity and management of rice-wheat cropping systems: issues and challenges. Field Crops Research. 2001; 69(2): 93-132. https://doi. org/10.1016/S0378-4290(00)00143-X.

56. Shah T. Climate change and groundwater: India's opportunities for mitigation and adaptation. Environmental Research Letters. 2009; 4(3): 035005. https://doi.org/10.1088/17489326/4/3/035005.

57. Yousuf I, Ghumman A, Hashmi H, Kamal M. Carbon emissions from power sector in Pakistan and opportunities to mitigate those. Renewable and Sustainable Energy Reviews. 2014; 34: 71-7. https://doi.org/10.1016/j.rser.2014.03.003.

58. Metz B, Davidson O, Bosch P, Dave R, Meyer L. Mitigation of climate change. Contribution of Working Group II to the Fourth Assessment Report of the Intergovernmental Panel on Climate Change (IPCC). 2007.

59. Mitigation CC. IPCC special report on renewable energy sources and climate change mitigation. 2011.

60. Hussain M, Liu G, Yousaf B, Ahmed R, Uzma F, Ali MU, et al. Regional and sectoral assessment on climate-change in Pakistan: Social norms and indigenous perceptions on climate-change adaptation and mitigation in relation to global context. J. Clean. Prod. 2018; 200: 791-808. https:// doi.org/10.1016/j.jclepro.2018.07.272.

61. Reilly JM, Schimmelpfennig D. Agricultural impact assessment, vulnerability, and the scope for adaptation. Climatic Change. 1999; 43(4): 745. https://doi. org/10.1023/A:1005553518621.

62. Matsumoto Ki. Climate change impacts on socioeconomic activities through labor productivity changes considering interactions between socioeconomic and climate systems. J. Clean. Prod. 2019; 216: 528-41. https://doi.org/10.1016/j. jclepro.2018.12.127

63. Naqvi A, Asif S, Ashfaq M, Ali Adil S, Ahmed A. Current Agricultural Production System of Punjab is Vulnerable to Climate Change: Impact Assessment. J. Agric. Res. 2017; 55(1).

64. Rehman A, Ashfaq M, Naqvi SAA, Adil S, Bashir K, Ahmad $A$, et al. Is climate change worsening the poverty of maize growers? Evidence from Punjab province of Pakistan. Ciencia e TecnicaVitivinicola. 2015; 30: 105-16.

65. Gul F, Jan D, Ashfaq M. Assessing the Impact of Climate Change Adaptation Strategies on Poverty Rates of Wheat Farmers in Khyber Pakhtunkhwa, Pakistan. Sarhad J. Agric. 2019; 35(2): 442-8. https://doi.org/10.17582/journal. sja/2019/35.2.442.448.

66. Gul F, Jan D, Ashfaq M. Assessing the socio-economic impact of climate change on wheat production in Khyber Pakhtunkhwa, Pakistan. Environmental Science and 
Pollution Research. 2019; 26(7): 6576-85. https://doi. org/10.1007/s11356-018-04109-7.

67. Baig IA, Ashfaq M, Naqvi SAA, Ahmed A, Hoogenboom G, Antle JM, et al. Ex ante impact assessment of wheat crop in Punjab-Pakistan. J. Appl. Environ. Biol. Sci. 2014; 4(7S): 358-63.

68. O’Neill BC, Carter T, Ebi K, Edmonds J, Hallegatte S, Kemp-Benedict E, et al. Meeting report of the workshop on the nature and use of new socioeconomic pathways for climate change research. HAL; 2012.

69. McDermid SP, Dileepkumar G, Kadiyala M, Nedumaran S, Singh P, Srinivasa C, et al. Integrated assessments of the impact of climate change on agriculture: An overview of AgMIP regional research in South Asia. 2015. https://doi. org/10.1142/9781783265640_0018.

70. Valdivia RO, Antle JM, Rosenzweig C, Ruane AC, Vervoort J, Ashfaq M, et al. Representative agricultural pathways and scenarios for regional integrated assessment of climate change impacts, vulnerability, and adaptation. Handbook of Climate Change and Agroecosystems: The Agricultural Model Intercomparison and Improvement Project Integrated Crop and Economic Assessments, Part 1: World Scientific; 2015; 101-45. https://doi. org/10.1142/9781783265640_0005.

71. Khaliq T, Gaydon DS, Cheema M, Gull U. Analyzing crop yield gaps and their causes using cropping systems modelling-A case study of the Punjab rice-wheat system, Pakistan. Field Crops Research. 2019; 232: 119-30. https:// doi.org/10.1016/j.fcr.2018.12.010.

72. Naseer AM, Ashfaq M, Hassan S, Abbas A, Razzaq A, Mehdi $M$, et al. Critical Issues at the Upstream Level in Sustainable Supply Chain Management of Agri-Food Industries: Evidence from Pakistan's Citrus Industry. Sustainability. 2019; 11(5). https://doi.org/10.3390/su11051326.
73. Taylor KE. A summary of the CMIP5 experiment design. http://cmip-pcmdillnlgov/cmip5/docs/Taylor_CMIP5_ designpdf. 2009.

74. Ruane AC, Goldberg R, Chryssanthacopoulos J. Climate forcing datasets for agricultural modeling: Merged products for gap-filling and historical climate series estimation. Agricultural Forest Meteorology. 2015; 200: 233-48. https:// doi.org/10.1016/j.agrformet.2014.09.016.

75. Rosenzweig C, Hillel D. Handbook of Climate Change and Agroecosystems: The Agricultural Model Intercomparison and Improvement Project (AgMIP) Integrated Crop and Economic Assessments-Joint Publication with American Society of Agronomy, Crop Science Society of America, and Soil Science Society of America (In 2 Parts): World scientific; 2015. https://doi.org/10.1142/p970.

76. Keating BA, Carberry PS, Hammer GL, Probert ME, Robertson MJ, Holzworth D, et al. An overview of APSIM, a model designed for farming systems simulation. 2003; 18(3-4): 267-88. https://doi.org/10.1016/S11610301(02)00108-9.

77. Jones JW, Hoogenboom G, Porter CH, Boote KJ, Batchelor WD, Hunt L, et al. The DSSAT cropping system model. 2003;18(3-4):235-65. https://doi.org/10.1016/S11610301(02)00107-7.

78. Hoogenboom G, Jones J, Wilkens P, Porter C, Batchelor W, Hunt L, et al. Decision support system for agrotechnology transfer version 4.0. 2004.

79. Boote KJ, Jones JW, Hoogenboom G, White JW. The role of crop systems simulation in agriculture and environment. International Journal of Agricultural Environmental Information Systems. 2010; 1(1): 41-54. https://doi. org/10.4018/jaeis.2010101303. 